\title{
FINANCIAL FEASIBILITY ANALYSIS OF PROCESSED CHOCOLATE BUSINESSAT TWINS CHOCOLATE HOME INDUSTRY IN PALU CITY
}

\author{
Abrar $^{\text {I) Lien Damayanti }}{ }^{2)}$ Yulianti Kalaba ${ }^{2)}$ \\ ${ }^{1)}$ Agribusiness Study Program Faculty of Agriculture, Tadulako University, Palu, \\ Email: Abrar.hiabbas93@gamil.com \\ ${ }^{2)}$ Faculty of Agriculture, Tadulako University, Palu
}

\begin{abstract}
Cocoa Agribusiness in Central Sulawesi still confronts many complex problems, such as low productivity due to PKB pests, low production quality. This becomes a challenge as well as investment opportunities in developing the business of chocolate product and achieve greater added value than cocoa agribusiness. This research aimed to know the income and financial feasibility obtained by Twins Chocolate Industry chocolate product production in Palu. The research was conducted at the Twins Chocolate Industry Jalan Rusa No. 13 Talise subdistrict Mantikulore Palu city Central Sulawesi on October to September 2016. The respondents consisted of one leader and two employees in the field of production and marketing. The results showed that the revenue obtained in the first year was Rp 25.7017 million, the second year was Rp 26.8927 million and in the third year was Rp 38,309,875. Feasibility levelsobtained by the PP for 2 Years and 2 Months were NPV Rp 11,927,788, an IRR of $22.75 \%$ and PI of 1.19. It means that Twins Chocolate industry was laboured because it met the eligibility criteria set.
\end{abstract}

Keywords: Chocolate Product, Financial Feasibility Analysis, Twins Chocolate Industry.

\section{INTRODUCTION}

The agricultural sector still shows an important role in the Indonesian economy. It is because the agricultural sector is still contributing to the gross domestic product, able to absorb the labor force, able to provide the diversity of the food menu, able to support the upstraeam and downstream industrial sector, able to increase farmers' income, and able to promote employment and agricultural products that can contribute a sizeable foreign exchange (Margaretha, 2011).

The cocoa bean is an export commodity that can contribute to increase state revenue. Indonesia is one of the main suppliers of cocoa in the world after Ivory Coast $(38.3 \%)$ and Ghana $(20.2 \%)$ with the presentation of $13.6 \%$. World demand for cocoa is increasing from year to year (BPS 2011). Indonesian cocoa plantations experienced rapid development since the early 1980s and in 2002, cocoa plantations in Indonesia is recorded covering an area of 914.051 ha. Most (87.4\%) of cocoa plantations are managed by people, $6.0 \%$ of the country estate and $6.7 \%$ private estates (Akhmad et al, 2014).

Based on the descriptions above, the main commodity is an initial step towards the development of agriculture which is based on the concept of efficiency to gain a comparative advantage and to face the globalization of trade. Based on the supply side, the main commodity is characterized by superiority in biophysical conditions, technological and socio-economic conditions of farmers in the region growth. The main commodity characterized by strong demand in both domestic and international markets based on the demand side. Socio-economic conditions are such as the mastery of 
technology, human resources, infrastructure e.g. market and customs of the local farmers (BPS 2011).

The development of the cocoa plants in Central Sulawesi is part of the agricultural sector which is considered the most consistent growth from year to year in a result production of the wide area and its productivity. These results are shown in Table 1.

Table 1 shows that the production of cocoa in Central Sulawesi tends to have increasing amount over the last 5 years. Production in 2010 amounted to 138,306 tonnes and then increased by 168,859 tonnes in the year 2011, whereas from the Year 2011 to the Year 2012 increased by 181,523 tonnes, and in the year 2013 increased by 195,846 tonnes, to reach 208,485 tonnes in 2014.

Table 1. Area, Production and Productivity of Cocoa Farming in Central Sulawesi, 2010-2014

\begin{tabular}{cccc}
\hline Year & $\begin{array}{c}\text { Area } \\
(\mathrm{Ha})\end{array}$ & $\begin{array}{c}\text { Production } \\
(\text { Ton })\end{array}$ & $\begin{array}{c}\text { Producivity } \\
\text { (Ton/Ha) }\end{array}$ \\
\hline 2010 & 166,732 & 138,306 & 0.829 \\
2011 & 195,725 & 168,859 & 0.862 \\
2012 & 295,874 & 181,523 & 0.613 \\
2013 & 284,125 & 195,846 & 0.689 \\
2014 & 291,445 & 208,485 & 0.715 \\
\hline Total & $1,233,901$ & 893,019 & - \\
\hline Average & $246,780.2$ & 178,603 & 0.742 \\
\hline
\end{tabular}

Source: The Central Bureau of Statistics Central Sulawesi (BPS 2015)
The process of economic development in a region pose a great opportunity for all economic activity, including industrial enterprises of all sizes, ranging from small, medium, and large businesses. Small and Medium Enterprises (SMEs) have an important role in contributing to the economy of a region. SMEs also play an important role in areas emerging especially the mitigation of poverty, unemployment, income distribution, and employment (Abdilah et al, 2015). It is expected to be a step for the government of of Palu city to move the production sector in a variety of businesses, especially the business of chocolate product to realize the goal of equitable national development.

One of the household industries that process chocolate is a business which is managed by Tutty who has been running since 2015 and is still using labor within the family and the business expected to increase the family income supplements from the processing of cocoa into chocolate snack with a variety of flavors. Based on data from the Department of Industry, Trade and Cooperatives Palu, stated that there are some agro-industries that produce products of chocolates. This can be seen in Table 2 .

Table 2 shows the raw material needed of each industry in Palu Chocolate was vary. Based on this data, the raw material needed of "Twin Chocholate" home industrywas at $52 \mathrm{~kg} /$ month, it was quite large when compared to the industry of Al Ikhsan who first stood up.

Table 2. Name of Industrial Raw Materials and Supplies Processed Assorted chocolates in Palu in 2015 .

\begin{tabular}{cllr}
\hline No & \multicolumn{1}{c}{$\begin{array}{c}\text { Industry Name } \\
\text { (UMKM) }\end{array}$} & \multicolumn{1}{c}{ Address } & $\begin{array}{c}\text { Raw Material Needs } \\
\text { kg/month }\end{array}$ \\
\hline 1 & Sa'adah Agency & Jln. Otista No.60 & 230 \\
2 & Rapavioka Coklat & Jln. Lasoso & 220 \\
3 & Mangun Coklat & Jln. Mangunsarkoro No.12 & 60 \\
4 & Merpati Coklat & Jln. Merpati & 52 \\
5 & Twins Chocolate & Jln. Rusa & 47 \\
6 & Al Ikhsan Coklat & Jln. Bakuku No.21 & 18 \\
7 & Moon's Coklat & Grand Tagari Blok C/9 & 12 \\
8 & Tadulako Coklat & Jln. Lasoso No.1 & \\
\hline
\end{tabular}

Source: Department of Industry and Trade of Central Sulawesi in 2016. 
Income is a primary goal of the company due to the company's operations in a good future or in other words that the income is a tool for survival. One of the things that influences the size of the revenue are the production capacity and product prices. The feasibility study is needed to be taken into consideration in a business. The feasibility study is a review of the financial aspects in order to determine the feasibility of the establishment of a business. The analysis is used to determine whether these efforts will be economically viable or not, because the activities carried out by an industry which hasmain purpose of economic benefits. Basically, cocoa processing activities is to run a company, therefore every activity must be economic attention to whether the production which is sold can provide decisive advantage with large resources of small amount of production.

Home industryof Twins Chocolate is an industry that is still only a year running and still have a relatively low capital, while the demand for chocolate is growing bigger so that consumer demand for these products have not been met, and yet there is no outlet for selling the products so that the product is offered directly to consumers, as well as the consumers who order. Venture capital constraints also hamper the industry in adding modern equipment, so that the use of the production means is still relatively modest. These reasons become the background for the researcher in his research in order to know more about the feasibility of income and thus Household Industry of Twins Chocolate really knows the business carried.

This Research aimed to (1) know the income of the chocolate product business at Twins Chocolate Industry in Palu City. (2) Know value of the eligibility financial of the chocolate product business at Twins Chocolate Industry in Palu City.

\section{RESEARCH METHODS}

Research Analysis of Revenue and Business Feasibility of Chocolate Product implemented in Household Industrial of Twins Chocolate in Palu city. Locations were selected intentionally (purposive) with the consideration; that the Home industry Twins Chocolate is one of the chocolate processing industry in the Palu city, and Twins Chocolate Industry still new and has not done any research. The research was conducted on September and October 2016. Respondent committed intentionally (purposive). Research respondents were consisted of one leader and two employees in the production and marketing who were involved in Twins Chocolate Industry that expected to provide information in accordance with the purpose of the research to be carried out.

Research Data Collection and Analysis Revenues Feasibility of Chocolate Product on Chocolate Twins Household Industries was consisted of primary data and secondary data. Primary data were obtained by direct observation and interviews with respondents, the owner / head of Twins Chocolate household industry by using questionnaires (Questionnaire). Secondary data were obtained from the relevant agencies and relevant literature in accordance with the purpose of research.

Answering the problems based on the first purpose, then, an approach used was revenue analysis. Operating revenue is the difference between revenue earned and all costs incurred by the home Industrial of Twins Chocolate in producing chocolate. Mathematical terms can be written as follows:

$$
\pi=T R-T C
$$

Information :

$$
\begin{array}{ll}
\pi & =\text { Income } \\
\text { TR } & =\text { Total Revenue } \\
\text { TC } & =\text { Total Cost }
\end{array}
$$

Information:

$$
\begin{array}{ll}
\mathrm{TR} & =\mathrm{P} \cdot \mathrm{Q} \\
\mathrm{TC} & =\mathrm{FC}+\mathrm{VC}
\end{array}
$$


Information :

$\pi=$ Profit / Income

$\mathrm{TR}=$ Total Revenue

$\mathrm{TC}=$ Total Cost

$\mathrm{P}=$ Product Pricing

$\mathrm{Q}=$ Number of Products

$\mathrm{FC}=$ Fixed Costs

$\mathrm{VC}=$ Variable Costs

Answering the problems in the second goal, then, approaching that was being used in feasibility analysis which is consisted of Payback Period (PP), Net Present Value (NPV), Internal Rate of Return (PP) and Profitability Index (PI).

According to Kashmir and Jafar (2003) model of computation used in calculating the payback period is as follows:

$$
\text { Payback Period }=\frac{\text { Invesment }}{\text { Net Cash/Year }} \times 12
$$

According to Kashmir and Jafar (2003) mathematically payback periods formula is as follows:

NPV $=$ Total PV Net Cash - Total PV Investment

According to Lihan and Yogi (2009) one way of calculating IRR with the following steps:

1. Determinie the specific DF (IRR1) to reach the number of NPV $=0$ or close to 0 (zero), then do it by trial and error (try and error) in order to obtain DF as IRR1 where NPV close to 0 (zero).

2. Determine the specific DF (IRR2) to reach the amount of negative NPV

3. Calculate IRR by using the following formula

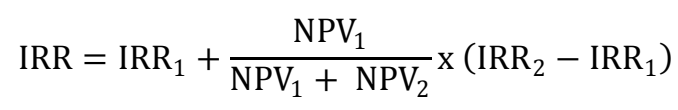

According to Kashmir and Jafar (2003) Profitability index (PI) or Benefit and Cost Ratio (B / C) is a ratio activity of current total net receipts present inestasi value. The means used to search for PI 8is as follows:

$$
\mathrm{PI}=\frac{\sum \text { PV Net Cash }}{\sum \text { PV Investment }}
$$

Scoring criteria :

If $\mathrm{PI}>1$, then the investment is accepted If $\mathrm{PI}<1$, then the investment is rejected

\section{RESEARCH RESULTS}

The production process is a series of activities to process raw materials and other adjuvants by using the equipment and labor to produce goods or products. Home industry of Twins Chocolate is one of the industries that engages in the production and sells of chocolate bars with good quality. Home industry of Twins Chocolate resulted the production of chocolate bars as much as 5,900 packs in 2016 with an increase of $25 \%$, i.e. from 472 packs rose becomes 590 packs on November and December 2016 due to the approaching festivities, the production lasted until the second and third year. The amount of production, the price and the value of production is shown in Table 3.

Table 3 shows that bar chocolate production of Home industry of Twins Chocolate in the first year was equal to 5,900 pack by boosting up the production amount up to $25 \%$ on November until December, and obtained the income Rp 88,500,000. On the second year, home industry of Twins Chocolate produced the cocoa bar as much as 7,080 packs and obtained income as much as Rp $106,200,000$ and third year obtained the income as much as Rp 120,360,000.

Table 3. The amount of chocolate Production and the income of Twins Chocolatehome industry every year.

\begin{tabular}{cccc}
\hline Year & $\begin{array}{c}\text { Production } \\
\text { /Packs }\end{array}$ & Price & $\begin{array}{c}\text { Revenue } \\
(\mathrm{Rp})\end{array}$ \\
\hline I & 5,900 & 15,000 & $88,500,000$ \\
II & 7,080 & 15,000 & $106,200,000$ \\
III & 7,080 & 17,000 & $120,360,000$ \\
\hline
\end{tabular}

Source. Primary data after processed, 2016 
Tabel 4. Chocolate Production cost per year of Twins Chocolate home industry

\begin{tabular}{cccc}
\hline Year & $\begin{array}{c}\text { Fixed } \\
\text { Cost(Rp) }\end{array}$ & $\begin{array}{c}\text { Variable } \\
\text { Cost(Rp) }\end{array}$ & $\begin{array}{c}\text { Total Cost } \\
(\mathrm{Rp})\end{array}$ \\
\hline I & $13,479,500$ & $49,318,800$ & $62,798,300$ \\
II & $16,479,500$ & $62,827,800$ & $79,307,300$ \\
III & $16,479,500$ & $65,570.625$ & $82,050,125$ \\
\hline
\end{tabular}

Source. Primary data after processed, 2016.

Total production expense of Twins Chocolate home industry represents the grand total of expense used in activity to produce product. The expense represents the related important matter with the production activity which is conducted by the Home industry of Twins Chocolate. Expense used in producing the chocolate is consisted of the fixed cost and the expense of production variable. The using of production cost per year at of Twins Chocolate home industry can be seen in Table 4.

Table 4 shows that the use of all costs in the production of chocolate at the Twins Chocolate home industry was consisted of fixed costs and variable costs in the first year of $\mathrm{Rp} 62,7983$ million, the second year of $\operatorname{Rp~79,307,300~and~the~third~}$ year of $\operatorname{Rp} 82,050,125$.

Revenue is the amount of money received by the company after deducting production expenses. Revenue is the difference between total revenue (TR) with a total cost of Production (TC) (Lani, 2013). Revenue Analysis is conducted in domistic industry of Twins Chocolate to know the level of profit per year generated from chocolate production. Income that is obtained by Home industry of Twins Chocolate after knowing acceptance difference from production rate with the production cost use. The income level which is accepted by Home industry of Twins Chocolate can be seen in Table 5.

Table 7 shows that the revenue from the production of Household Industry Twins Chocolate in the first year was Rp 25,701,700 by increasing the production up to $25 \%$ from November to December. The second year income of Twins Chocolatehome industry was Rp 26,8927 million and the third year income of Twins Chocolate home industry was Rp 38,309,875, decreased from the previous year because it has not raised the price of the product.

Calculating the feasibility of a business that uses the calculation Payback Period (PP), Net Present Value (NPV), Internal Rate of Return (IRR), and Profitability Index (PI) then it must be known cash flow (Cash Flow). Analysis of an investment, there are two cash flows such as cash flow (Cash Outflow) that occurs due to the expenses of the investment, and cash inflows (Cash Inflow) that occurs as a result of the benefits generated by an investment. Cash inflows (Proceed) are the net profit after tax plus depreciation cost of the tools used in the production process. Cash inflows can be seen in Table 6.

Tabel 5.Chocolate Production Income Per Year of Twins Chocolate Home Industry

\begin{tabular}{crrr}
\hline Year & Revenue $(\mathrm{Rp}) /$ Year & Total cost $(\mathrm{Rp}) /$ Year & Income $(\mathrm{Rp}) /$ Year \\
\hline I & 88.500 .000 & 62.479 .500 & 25.701 .700 \\
II & 106.200 .000 & 79.307 .300 & 26.892 .700 \\
III & 120.360 .000 & 82.050 .125 & 38.309 .875
\end{tabular}

Source : Primary Data after being processed, 2016 
Table 6. Cash Flow to the home industry of Twins Chocolate in Palu period 2016-2018

\begin{tabular}{cccccr}
\hline Year & EAT & Depreciation & Proceed & Df 12\% & PV Net Cash \\
\hline I & $25,701,700$ & $1,164,500$ & $26,866,200$ & 0,893 & $23,987,679$ \\
II & $26,892,700$ & $1,164,500$ & $28,057,200$ & 0,797 & $22,367,028$ \\
III & $38,309,875$ & $1,164,500$ & $39,474,375$ & 0,712 & $28,097,080$ \\
\hline \multicolumn{7}{l}{ Total PVNet Cash } \\
\hline
\end{tabular}

Source : Primary data after proceed, 2016

Table 7. Results of the calculation of financial feasibility in Twins Chocolatehome industry in Palu period 2016-2018.

\begin{tabular}{cll}
\hline No & \multicolumn{1}{c}{ Investment Criteria } & \multicolumn{1}{c}{ Value } \\
\hline 1 & Payback Period (PP) & 2 Years and 2Months \\
2 & Net Present Value (NPV) & Rp 11,927,787 \\
3 & Internal Rate of Return (IRR) & $22.17 \%$ \\
4 & Profitability Index (PI) & 1.19 \\
\hline
\end{tabular}

Source : Primary data after proceed, 2016

Table 6 shows the net cash in the first year Rp 26866.200 with a discount factor of $12 \%$, the PV net cash of $\mathrm{Rp}$ 23,987,679. The second year of Rp 28.057.200 with a discount factor of $12 \%$, the PV net cash of Rp 22.367.028. Third year net cash of Rp 39.474.375 with a discount factor of $12 \%$, the PV net cash of $\mathrm{Rp} 22,004,754$. Total net cash at the PV Twins Chocolate home industry was Rp 74.451.787.

Based on the calculation of financial feasibility criteria on Home industry Twins Chocolate obtain Payback Period (PP) for 2 years and 2 month. That is, in this period of investment costs incurred will be back in the industry is feasible because the payback period was less than the economic life of 3 years. Results Net Presents Value (NPV) was Rp 11,927,787. This indicated that the positive NPV (NPV >0), so declared eligible to run. Internal Rate of Return (IRR) obtained amounted to $22.17 \%$. That was eliglible industry to run because the rate of return greater than the interest rate applicable (12\%), while the result of the calculation Profitability Index (PI) was a value of $1.19>1$. It means that $\mathrm{PI}$ is greater than 1 (one), so that the business is feasible to run.

\section{CONCLUSION AND SUGGESTION}

\section{Conclusion}

Results of the research conducted on the Twins Chocolatehome industry:

1. Income that was derived by Twins Chocolate home industry was Rp 25,701,700 million in the first year and $\mathrm{Rp} 26,892,700$ in the second year and the third year industry gained profit Rp 38,309,875.

2. Feasibility of business on Twins Chocolate Home industry obtained Payback Period for 2 years and 2 months, Net Present Value of $\mathrm{Rp}$ $11,927,787$ during the period 20162018, the Internal Rate of Return $22.17 \%$ and Profitability Index of 1.19 . Based on these results, the project is feasible to be developed because it meets the eligibility criteria in the set.

\section{Suggestions}

Advice that can be given on the results of the research that has been done on 
the Twins Chocolate home industry are as follows:

1. It is expected that The Home industry of Twins Chocolate further improve the production and the product quality so that the income increases.

2. It is expected that The Home industry of Twins Chocolate makes book keeping in performing the production, so that the flow of cash coming in and out can be seen more clearly.

3. For the government, they need to pay attention to small-scale industries and to disseminate quality products to the industry so that the Household industry Twins Chocolate may develop as well as earned income increases, given the industry could provide jobs to reduce the unemployment rate in the Palu city

\section{BIBLIOGRPHY}

Abdilah Afiayah., Muhammad Saifi., Dwiatmanto., 2015. Analisis studi kelayakan usaha pendirian Home industry (studi kasus pada home industry cokelat "cozy" kademangan blitar.Jurnal Administras iBisnis (JAB)|Vol. 23 No. 1

Akhmad, Humam Hamid, Romano dan Anton Yulianda., 2014. Analisis Rantai Nilai Dan Nilai Tambah Kakao Petani Di Kecamatan Paya Bakong Dan Geurudong Pase Kabupaten Aceh Utara. Jurnal Agriseb Vol (15) No. 2 , 2014

Badan Pusat Statistik., 2011. Indikator Ekonomi., BPS,. Jakarta - Indonesia

Badan Pusat Statistik., 2015. Luas Areal dan Produksi Usahatani kakao. BPS., Palu. Sulawesi Tengah

Dinas Perindustrian, Perdagangan dan Koperasi 2016. Nama-nama Industri Pengolahan Cokelat di Kota Palu. Palu, Sulawesi Tengah.

Kasmir dan Jakfar, 2003. Studi Kelayakan Bisnis. Edisi Kedua. Prenada Media. Jakarta

Lani Maria Angelin Lawidu, 2013. Analisis Titik Pulang Pokok Usaha Kerajinan Tangan Kayu Hitam (Ebony) pada Ud. Krisna Karya Ebony di Kota Palu. Jurnal Agrotekbis $1(2): 177-184$

Lihan dan Yogi, 2009. Studi Kelayakan Bisnis. Poliyama Widyapustaka. Jakarta

Margaretha P.S, 2011.Analisis Struktur Biaya Produksi Dan Kontribusi Pendapatan Komoditi Kakao (Theobroma Cacao L) Di Desa Latu. Jurnal Agroforestri Volume VI Nomor 2 Juni 2011 